\title{
DOUBLETALKING THE HOMOPHONIC SUBLIME: COMEDY, APPROPRIATION, AND THE SOUNDS OF ONE HAND CLAPPING ${ }^{1}$
}

\section{A B S T R A C T}

Homophonic translations create poems that foreground the sound of the original more than the lexical meaning. I begin by discussing the concept of "sound writing," referencing Haroldo de Campos's concept of "transcration," Pound's "transduction," and the concept behind calques. I then consider my homophonic translation of Finnish poet Leevi Lehto follows and Ulises Carrión's isophonic translation. After noting Basil Bunting idea that meaning is carried by sound more than lexical content, I discuss Khelbnikov's approach to zaum (transense), and soundalike works based on bird song and animal sounds. The essay then takes up several specific examples: David Melnick's homophonic translation of Homer, Pierre Joris's voice recognition translation of Magenetic Fields, and Jean Donneley's version of Ponge. The essay concludes with a discussion of Caroline Bergvall's Drift, her version of "The Seafarer" as well as her Chaucer transcreations. A central part of the essay references "homophonic" translation in popular culture, in particular the "doubletalking" of Sid Caesar," the most popular TV comedian of the early 1950s. A discussion of his work in the context of American Jewish comedy is central to the lecture. But other more recent popular example of the homophonic are discussed with special reference to cultural appropriation.
Charles Bernstein

University of Pennsylvania

charles.bernstein@english.upenn.edu
KEY WORDS

20TH CENTURY POETRY

POETICS

TRANSLATION

HOMOPHONICS

SID CAESAR

LOUIS ZUKOFSKY

EZRA POUND

CAROLINE BERGVALL

DAVID MELNICK

YIDDISH

ESPERANTO

APPROPRIATION 
Who am I? I am not a straight stonemason,

Neither a shipbuilder, nor a roofer,

I am a double-dealer, with a double soul,

A friend of night, and a daymonger.

Osip Mandelstam²

He speaks in six known and six unknown languages.

Daniil Kharms ${ }^{3}$

\section{SOUND WRITING}

Never met a pun I didn't like.

I'm a veritable Will Rogers, with plenty of roger but without the will to say enough's enough already. All instinct. Like a Brooklyn Ahab stalking a whale in the back yard or a curmudgeonly Odysseus hurtling toward his sirens.

But wait a sec.

This is not the opening of a nightclub act.

Jokes are not arguments.

I am for avant-garde comedy and stand-up poetry.

That is, to my way of seeing it, there are only two kinds of writing: Sound and unsound. ${ }^{4}$ Stand-up and stand-down. Wanted and spurned. Risible and bereft. Incomprehensible and desperate. Performed and blank.

What a glorious idea Truman Capote had for typing that wasn't writing, as he said of Jack Kerouac in 1959 on David Susskind's TV show (Capote meant it as an insult). ${ }^{5}$

Can there be verbal sound without meaning? Soul without soullessness? Body without flesh? Listening without hearing? Hope sans history?

But this is going too fast.

Let me start at the beginning.

When Vincent Broqua asked me to come to Paris for a conference on homophonic translation (not homophobic, don't even THINK of that here!), he proposed to call it "Sound - Translation - Writing." I suggested "sound/ writing"' 6 'the sturdy resources of [the] ear,' as Robert Creeley once wrote me, echoing Charles Olson's 'by ear, he sd.' 
"Homophonic translation" is a genre of "sound/writing." Sound/writing provides a broader context for the homophonic imaginary and includes modernist European sound and zaum poetry and within the larger context of radical translation, what Haroldo de Campos calls transcreation $^{8}$ and Ezra Pound calls traduction (in the sense of transduction).

Pound often avoided using the verb "to translate," preferring a calque such as "to bring over" that recalls the etymology of the conventional term. When his first translation of Cavalcanti's "Donna mi prega" appeared in The Dial in 1928, he called it a "traduction," replacing the usual word with a Latinism derived ultimately from traductio, "a leading across."

Calque is a loan-translation, a word-for-word carrying over from one language to another (as vers libre to free verse), from the French calquer, to trace.

Homophonic translation is a form of sound tracing.

(My term is echopoetics.)

The homophonic sublime is a form of délire in Jean-Jacques Lecercle's sense, either phony or toney, depending on how you frame it. ${ }^{10}$ At its core, homophonic translation refuses a Cartesian split between sound and sense, seeing sense as never more than an extension of sound. At every moment it refutes the idea that meaning can be displaced from sound or that reference has an arbitrary, rather than motivated, relation to acoustic rhythm, sound patterning, and aural iconicity.

From a pragmatic point of view, any individual poem will fall short of the homophonic sublime. In that sense, homophonic translations might be heard as pushing in a direction, correcting a course, re-embodying the word. The homophonic is poetry that leads by the ear, foregrounding aurality: poetry that resists cutting the umbilical $\mathrm{c}(\mathrm{h})$ ords between translated and translation, source and target, original and copy, essence and accident, brain and mass, figure and ground, spirit and materiality, irony and sincerity, singer and song, imaginary and real, semantic and antic. The homophonic sublime is a necessary improbable of poetry, a rebuke to rationality in the name of linguistic animation.

In its archetypical form, homophonic translation creates a perfect mirror of the sound of the source poem into the target poem. It is mimesis by, and as, other means. While homophonic translation is related to sound poetry, the premise is that it extends an original text into a new language using real, not made-up, words of the target language. In a Borgesian pluriverse, the ideal homophonic 
translation would be heard by the speakers of the source language as if it were the original poem while heard by the speakers of the target language as a strange word concoction but still in their own tongue. I tried this with "Sane as Tugged Vat, Your Love," my 1993 homophonic translation of Leevi Lehto's "Sanat tulevat yöllä" ("Word Arrive by Night:) ${ }^{11}$ Finnish speakers hear it as if it is their own language, yet they cannot make out the words:

Olen sanonut tästä jo monta kertaa.

Talon jokaisessa veeseessä on valo.

Sillat virtaavat itään.

Sanat tulevat yöllä koputtamatta.

O when sanity tasted of muffled curtsy.

Talon -- Jokasta's vivisected valor.

Silly virtual item.

Sane as tugged vat, your love, kaput.

I've said about this many times before.

In every toilet of the house there is a light on.

Bridges flow east.

Words arrive by night without knocking.

Tämä tapahtui kaukaisessa maassa tässä lähellä.

Olen sanonut tästä jo monta kertaa.

Talon jokaisessa veeseessä on valo.

Sillat virtaavat itään.

Tamed tapestry's caressed master's tasseled luaus.

O when sanity tasted of muffled curtsy.

Talon -- Jokasta's vivisected valor.

Silly virtual item.

This happened in a faraway country nearby.

I've said about this many times before.

In every toilet of the house there is a light on.

Bridges flow east.

Maaseudulla punt eivät vielä olleet lähteneet juoksuun.

Tämä tapahtui kaukaisessa maassa tässä lähellä.

Olen sanonut tästä jo monta kertaa.

Talon jokaisessa veeseessä on valo. 
Medusa pouts as vat's veil's oldest lament jokes.

Tamed tapestry's caressed master's tasseled luaus.

$\mathrm{O}$ when sanity tasted of muffled curtsy.

Talon -- Jokasta's vivisected valor.

In countryside the trees had not broken into run yet.

This happened in a faraway country nearby.

I've said about this many times before.

In every toilet of the house there is a light on.

Presidentti itse oli täysin lamaantunut.

Maaseudulla puut eivät vielä olleet lähteneet juoksuun.

Tämä tapahtui kaukaisessa maassa tässä lähellä.

Olen sanonut tästä jo monta kertaa:

President -- he itsy, oily, tainted, laminated.

Medusa pouts as vat's veil's oldest lament jokes.

Tamed tapestry's caressed master's tasseled luaus.

$\mathrm{O}$ when sanity tasted of muffled curtsy.

The President himself was utterly paralysed.

In countryside the trees had not broken into run yet.

This happened in a faraway country nearby.

I've said about this many times before:

Talon jokaisessa veeseessä on valo,

sillat virtaavat itään ja

sanat tulevat yöllä koputtamatta.

Talon -- Jokasta's vivisected valor.

Silly virtual item, yah!

Sane as tugged vat, your love, kaput.

In every toilet of the house there is a light on,

Bridges flow east, and

Words arrive by night without knocking.

There is a kind of perverse pleasure in trying to create the same (homo) from difference (hetero): homophonics is pataque(e)rical. The homophonic sublime is also the dream of a pure poetry, words for their own sake, the cry of their occasion, "COME CI": only this and nothing more. ${ }^{12}$ 
A pure homophonic (or isophonic or synphonic) translation would be the same words brought into a new language, not at all uncommon for proper names and place names. The Mexican conceptualist Ulises Carrión plays on this possibility with his "The translation of 'Pedro Páramo," a reference to the 1955 novel by Juan Rulfo:
to English: Pedro Páramo
to French: Pedro Páramo
to Italian: Pedro Páramo
to German: Pedro Páramo
to Portuguese: Pedro Páramo
to Dutch: Pedro Páramo ${ }^{13}$

Homophonic translation is parasitic: a parasite that may want to live symbiotically with its source or may wish to replace it, at least in becoming a new poem in its own right, autonomous, no longer dependent on the original but an original of its own.

In "The Use of Poetry," Basil Bunting writes about reading Persian, German, Italian, and Welsh poetry to a class that did not know those languages. $\mathrm{He}$ genially insists that the students would get as much out of hearing a foreign language poem as hearing one in their own language, since pronouncing a word is more important than knowing its meaning. ${ }^{14}$ While Bunting's recitation of foreign language poems incomprehensible to his students was a quite serious endeavor, I see a connection with postwar American comedian Sid Caesar's "doubletalking" - deliriously funny live verbal improvisations that sound like Italian, German, and Japanese speech but are composed on the tongue with made-up strings of words. ${ }^{15}$ Where Caesar gets laughs, Bunting gets poetry.

Bunting's insistence on sound over meaning is an extension of his framing of poetry in terms of music. Perhaps the most common experience related to Bunting's modest proposal is listening to an opera sung in a language you do not know and feeling you are missing nothing, indeed, preferring to hear the original to having the libretto sung, in translation, in your own language; and, moreover, preferring to listen without subtitles. It's no coincidence that opera parody is crucial to Caesar's doubletalking.

The zaum poems of Russian futurians Velimir Khlebnikov and Aleksei Kruchenykh were composed of synthesized or invented words that, whether intend or not, broke down the barriers of nationalist tongues and evoked species-wide listening, something that might be compared to Esperanto, despite 
the radical differences. Khlebnikov's "Incantation by Laughter" (1909) is the best-known zaum poem. My transcreation follows the sound:

We laugh with our laughter [O, rassmeites', smekhachi!]

loke laffer un loafer [O, zasmeites', smekhachi]

sloaf lafker int leffer [Chto smeyutsya smekhami]

lopp lapter und loofer [chto smeyanstvuyut smeyal'no]

loopse lapper ung lasler [O, zasmeites' usmeyal'no!]

pleap loper ech lipler [O, rassmeshishch nadsmeyal'nykh]

bloop uffer unk oddurk [smekh usmeinykh smekhachei!

floop flaffer ep flubber [O, issmeisya rassmeyal'no]

fult lickles eng tlickers [smekh nadesmeinykh smeyachei!]

ac laushing ag lauffing uk [Smeievo, smeievo,]

luffing ip luppling uc [Usmei, osmei, smeshiki, smeshiki,]

lippling ga sprickling [Smeyunchiki, smeyunchiki,]

urp laughter oop laughing [O, rassmeites', smekhachi!]

oop laughing urp laughter [O, zasmeites', smekhachi! ${ }^{16}$

In modernist poetry, zaum is the most radical - and perhaps hysterical-extension of the sublime ideal of a poem being only itself, a cry of its occasion, "only this," overthrowing a subservience to representational meaning, or a parasitic relation to an original. Khlebnikov may have desired a deeper ur-Slavic but he also wrote of his desire for "a single human conversation"; in some sense "beyonsense" - zaum echoes international socialism. ${ }^{17}$ On the Dada side, there are the sound poetry inventions at the Cabaret Voltaire, one hundred years ago, especially the work of Hugo Ball; and the ur-text of sound poetry, composed from 1922 to 1932, Kurt Schwitters's "Ursonate." ${ }^{18}$ Within American popular religious culture, there is speaking in tongues (glossolalia) - the spontaneous utterance, as if possessed, of an unintelligible or foreign language, which Jennifer Scappettone contrasts with xenoglossia. ${ }^{19}$ Within American popular music, consider the scat singing of Ella Fitzgerald and Cab Calloway.

Reuven Tsur argues that you can't hear verbal utterances as non-verbal, but a poem can surely try to entice you by foregrounding the physical materiality of language, short-circuiting semantic processing. ${ }^{20}$ Then again, what's verbal and what's not is a matter of framing. We can hear a brook talking to us, can make animal sounds, and even turn the clackity-clacking of a sewing machine into a song. 
The transformation of voicing or homophonically mimicking mechanical or machine sounds is its own genre of "sound-alike" poems. In Gertrude Stein's "If I Told Him: A Completed Portrait of Picasso" (1923), she echoes the sound of a shutter opening and closing: 'Shutters shut and open so do queens. Shutters shut and shutters and so shutters shut and shutters and so and so shutters and so shutters shut and so shutters shut and shutters and so. ${ }^{21}$ Then jump ahead to 2012 and Michael Winslow's mimicking the sound of 32 different historical typewriters. ${ }^{22}$

In Western poetry, birdsong has been a foundational metaphor for poetry, especially the nightingale's song. The earliest homophonic poetry would then be mimicry of birdsong in human language. Robert Grenier took this almost literally, writing a series of poems in 1975, Sentences Toward Birds that transcribed, into "the American," the "actual" sounds of birds in his immediate environment. Here are three of the poems, which, like his later Sentences, are each printed on individual cards:

why you say you see later

didn't see go to a

A BIRD / who would call / not for but for you / in the day ${ }^{23}$

More recently, Hanna Tuulikki's “Air falbh leis na h-eòin - Away with the Birds" (2010 to 2015) has explored the "mimesis" of bird sounds in Gaelic poetry and song. ${ }^{24}$

In aaaaw to zzzzd: The Word of Birds, John Bevins not only provides a "lexicon" of birdsongs - "chinga, chinga, chinga" is the homophonic signature of the swamp sparrow - but also a set of "mnemonics," such as the song sparrow's lyric refrain, "maids, maids, maids, put on your tea, kettle, kettle, kettle," 25 which makes me burst into song, as if this is Broadway musical:

Maids, maids, maids

Put on your tea

Kettle, kettle, kettle.

No time to waste

Get out your bass

Fiddle, fiddle, fiddle.

Young lads make haste

Dance to your love's

Riddle, riddle, riddle. ${ }^{26}$ 
Bevins also suggests a motto for the homophonic sublime is his adaption of Walter Pater on music - "All art aspires to the condition of birdsong" (p. 15).

But perhaps the ultimate revenge of the long tradition of homophonics belongs to Sparkie Williams, "the talking budgie," a bird who, in the mid-1950s, was able to parrot a wide range of English words, mimicking human speech. ${ }^{27}$

A decade after Sparkie, Michael McClure's Ghost Tantras (1964) features a partially invented vocabulary that he calls "beast language" (guttural, expressive), which brings to mind a kind of primitive zaum (McClure references Vladimir Mayakovsky). McClure wanted to find a level of language that invoked animality:

Grahhr! Grahhhr! Ghrahhhrrr! Ghrahhr. Grahhrrr.

Grahhr-grahhhhrr! Grahhr. Gahrahhrr Ghrahhhrrrr.

Gharrrrr. Ghrahhr! Ghrarrrrr. Ghanrrr. Ghrahhhrr.

Ghrahhrr. Ghrahr. Grahhr. Grahharrr. Grahhrr.

Grahhhhr. Grahhhr. Gahar. Ghmhhr. Grahhr. Grahhr.

Ghrahhr. Grahhhr. Grahhr. Gratharrr! Grahhr.

Ghrahrr. Ghraaaaaaahrr. Grhar. Ghhrarrr! Grahhrr.

Ghrahrr. Gharr! Ghrahhhhr. Grahhrr. Ghraherrr.

The 1964 and 1966 recordings he made reading his poems to lions are powerful poetic documents, notable for how much more expressive and poignant are the roars of the lions than are the homophonic translations of the poet, whose human language echoes wanly against the formidable sounds of the beasts. ${ }^{28}$ Wittgenstein famously remarked, 'Wenn ein Löwe sprechen könnte, wir könnten ihn nicht verstehen,' a homosyntactical (word-for-word) translation is 'If a Lion speak could, we could him not understand. ${ }^{29}$ But when the lion roars, in a duet with McClure's mimicking, we hear the sound as song, a wail, perhaps a lament. The lion is growling at the human intruder's appropriation, as if to say I am the king of my own language, do not mock me. And growling at us, the unseen listeners: beware!

Listening to a poem or opera in a language foreign to you, but feeling you get it all the same, is a far cry from homophonic translation: it leaves the original just as is, the foreignizing occurring in the listener's response. If the aim of a poem is to foreground the materiality of sound, then listening to a language you don't know is a kind of poetic experience. But that only goes so far. Listening to a poem in language you don't know gets less interesting the longer it goes 
on; entropy sets in faster than a mosquito dodging a fly swatter. Sid Caesar's doubletalk is hilarious because it is exaggerated in its stereotyping and because you know he is going on nerve: it's a high-wire act and the wire is not that long. In contrast, homophonic translation allows for extensions and textual subtly since it goes beyond imitation into commentary and because it is able to create a new poem in the new language.

\section{WOT WE WUKKERZ WANT}

Let me to make a brief detour in my account to consider Edgar Allan Poe's "The Philosophy of Literary Composition," published in 1846, near the end of the troubled poet's life. Poe's delightfully bizarre paean to artifice is, in part, a send-up of spontaneously inspired, frenzied, sincere verse, what Poe calls "ecstatic intuition." Writing about "The Raven," Poe claims that the origin of a poem is a set of logically predetermined effects, including sound effects: meaning comes after. In effect, Poe attempts to treat verbal composition as if it were musical composition. Poe's elaborate and impossible rules for poetic composition bring to mind Sid Caesar's grifter-like elaboration of impossible rules for a card game in his early 1950s sketch "The Poker Game." ${ }^{\prime 30}$ Both Poe and Caesar offer a kind of doubletalk, or talking out of both sides of the mouth, though, in these cases, not deceptively, since their discourse foregrounds the absurdity, even though performed with straight faces. In the comic pathos of Poe's insistence on the author's total control of the poem through the rigidly pre-determined, Poe never breaks character, that of the author whose sole aim is beauty, achieved by maximizing melancholy (not to say pathos). Poe elaborates his doubletalk with absolute conviction. Like Caesar, Poe aimed to please "the popular and the critical taste."

Both Baudelaire's and Mallarmé's translations of “The Raven” (1865 and 1875, respectively) swerve toward the homophonic, often echoing Poe's exact sound patterns. ${ }^{31}$ Even if you don't know French, you'd recognize "The Raven" if the translations were performed. A performed Yiddish translation by I. Kissen is always already a homophonic translation. "T2 "The Raven" is as identifiable as Beethoven's Fifth, and if you don't know Yiddish, it can seem as if it is doubletalk.

The modern history of radical translation in American poetry might reasonably with Pound's Chinese adaptions but I want now to briefly cite his two translations of Guido Cavalcanti (1250-1300), "Donna mi prega," the first from 1928, the 
second from 1934. Pound gives the constraints, worthy of Poe's "Philosophy of Composition" or Caesar's poker rules: "Each strophe is articulated by 14 terminal and 12 inner rhyme sounds, which means that 52 of every 154 syllables are bound into pattern." ${ }^{33}$

Because a lady asks me, I would tell

Of an affect that comes often and is fell

And is so overweening: Love by name.

E'en its deniers can now hear the truth. (1928, Pound's Cavalcanti, 171)

A lady asks me

I speak in season

She seeks reason for an affect, wild often

That is so proud he hath Love for a name

Who denys it can hear the truth now (1934, Pound's Cavalcanti, 179)

In 1940, at the beginning of World War II, Louis Zukofsky took the Cavalcanti translations to another dimension. What he produced was not a homophonic translation but rather a sound transcreation that radically accented the poem, making it, in part, an ethnic dialect poem, a sort of Yiddish doubletalking, where doubletalking implies bilingualism and double consciousness. ${ }^{34}$ As with his inaugural "Poem Beginning 'The," Zukofsky radically engaged an American vernacular, following the model of Pound and Williams, and he brought it home, to a mamaloshen (mother tongue), homey and homely, but with a majestic beauty brought over from the sound structure of the Cavalcanti:

A foin lass bodders me I gotta tell her

Of a fact surely, so unrurly, often'

' $r$ 't comes 'tcan't soften its proud neck's called love mm ... ${ }^{35}$

Perhaps the closest recent work of this kind - a translation into a marked, comic dialect, with accent über alles - is the riotous "The Kommunist Manifesto or Wot We Wukkerz Want" - "Redacted un traduced intuht' dialect uht' west riding er Yorkshuh bi Steve McCaffery, eh son of that shire" in 1977. ${ }^{36}$

\section{DOUBLETALK}

Discussion of homophonic translation is generally placed in the context of radical poetic innovation. I want to contrast that lineage with two examples from popular culture, one from the postwar American comic Sid Caesar and the other from Benny Lava, a recent viral YouTube video. 
Doubletalk, as Caesar uses the term, is homophonic translation of a foreignlanguage movie, opera scenario, or everyday speech into an improvised performance that mimics the sound of the source language with made-up, zaum-like invented vocabulary. Consider an uproarious 2015 performance by French poet Joseph Gugliemi, where he performs a made-up language under the guise of reading a poetry text, which at one point he shows to be all blank pages. ${ }^{37}$ In contrast, literary homophonic translation begins with a defined foreign-language poem as source text and creates a new work in English that mimics the sound of the original.

The best example of Caesar's "double-talk" is a concert in which he moves through four languages, starting with French and moving to German and Italian, ending with Japanese (replete with recognizable anchor words, such an Mitsubishi, Datsun and sushi). ${ }^{38}$ Taken as a whole, this five-minute performance is macaronic - a burlesque jumble or comic hodgepodge of different languages. The camera pans to the audience during each segment to show benign and approving laughter. The serial movement from language to language also suggests a nomadic display of mutli-lingual code-switching. It brings ... home ... the final line of Charles Reznikoff's 1934 poem about diaspora:

and God looked and saw the Hebrews

citizens of the great cities, talking Hebrew in every language under the sun..$^{39}$

Caesar was the most important and influential comedy star of early American television, a key member of a generation that included Lenny Bruce (born Leonard Schneider in 1925), Jackie Gleason (born 1916), Ernie Kovacs (born 1919), and Jerry Lewis (born Joseph [or Jerome] Levitch in 1926). Isaac Sidney "Sid" Caesar was born in 1922 and died in 2014. His parents were Jewish immigrants, his father was from Poland and mother from Russia, both coming to New York as children, which means that Yiddish would have been their home language.

Yiddish is a nomadic language, not based in any nation but creating a common tongue for diasporic Jews in Poland, Hungary, Russia, and America, among other places. While sometimes thought to be a dialect of German, Yiddish is its own language, spoken by people who did not necessarily know German. As a consequence of the Systematic Extermination of the European Jews, compounded by Israel's turn against Yiddish by selecting Hebrew as its national language, Yiddish came to be a dead language, like Latin, though it persists, with vitality, in pockets. 
In Bridges of Words: Esperanto and the Dream of a Universal Language, Esther Schor tells the story the invention of Esperanto by L. L. Zamenhof (1859-1917), an Eastern European Jew who grew up speaking Russian at home, Polish and German for business, Yiddish with other Jews, and Hebrew in synagogue. Zamenhof said that the hostility of one group of language speakers to another 'made me feel that men did not exist, only Russians, Poles, Germans, Jews, and so on. ${ }^{40} \mathrm{He}$ conceived Esperanto as a way to overcome ethnic and national barriers, which echoes, while departing from, Khlebnikov's "single human conversation" (and given zaum's "magical" derivations from Russian root words). Prior to his 1887 manifesto for Esperanto, Zamenhof had gone through a proto-Zionist period, where he advocated a Latin-scripted Yiddish. His vision for Esperanto's universality, in contrast, pushed back against antiSemitic projections of a secret Jewish language. Then again in 1901, Zamenhof proposed Esperanto for an ethically (rather than ethnically) based Jewish language, an alternative to the liturgical Hebrew and the polyglot ("jargonized") Yiddish.

'Instead of being absorbed by the Christian world, we [Jews] shall absorb them,' Zamenhof proclaimed in 1907 (pp. 82, 132). Schor comments that, in this context, Judaize means not to turn into Jews but to make justice and fraternity our foundation.

In his autobiography, Caesar tells a story that brings Zamenhof to mind (and ear). At his father's restaurant, where he worked, speakers of different language groups sat at different tables and Caesar would go from table to table mimicking the sounds of the customer's native tongues, much to their delight. The scene recalls lines by Hebrew poet Avot Yeshurun (born 1904) addressed to his mother, in which the poet expresses his sense of the loss of Yiddish, his mother/ other tongue, while evoking a primal experience of doubletalk: 'You who hear a language in seventy translations / at night in the garden of Dizengoff Square. ${ }^{\text {'41 }}$

Caesar's first cited (but not recorded) use of doubletalk was from Six On, Twelve Off, a Coast Guard review that he did with Vernon Duke in 1944 (Where Have I Been, 50-51). The doubletalk was part of a routine called "Conversation between Hitler and Donald Duck" - Caesar did both parts. The bit was likely inspired by the 1943 Walt Disney / RKO propaganda cartoon Der Fuehrer's Face, directed by Jack Kinney and originally titled Donald Duck in Nutzi Land, which won the Academy Award for Best Animated Short Film, though it was subsequently suppressed for fifty years. This sidesplitting short features the song Spike Jones made famous in 1942, "Der Fuehrer's Face," which was written by 
Oliver Wallace. Donald Duck in Nutzi Land bears a resemblance to Ducktators, directed by Norman McCabe (WB / Looney Tunes, 1942) as well as to Daffy Duck - the Commando, directed by Fritz Freleng (WB / Looney Tunes, 1943). Daffy - the Commando features snippets of parodic Nazi-inflected doubletalk and ends with Hitler giving a doubletalk speech (that is, a homophonic version of Hitler oratory), which is stopped by Donald hitting him with giant mallet after which Hitler stutters and screams. ${ }^{42}$

But before Caesar or Looney Tunes did their German doubletalk, there was Charlie Chaplin's extended homophonic translation of a Hitler speech in The Great Dictator from 1940: doubletalk salted with English words. That speech is given by the dictator Adenoid Hynkel, whose double is Schultz, the Jewish barber.

Homophonic works are usually funny, if not outright comic. They succeed because they have a sense of humor about the apparent absurdity of the idea. It's the humor, and the sense of identification with the other, that inflects the homophonics of Zukofsky and Caesar, both of who grew up in a Yiddishspeaking household but for whom English was, if not the mother tongue, than the father tongue, the language they mastered. Ironically, for Caesar, doubletalk was not deceptive or artificial but a honing/homing into the language-spring of mamaloshen. Indeed, Caesar notes that some of his first jokes were based on translinguistic puns and mishearing between Yiddish and English, which greatly amused his audience, who were making their way to being American by moving from Yiddish to English. Caesar credits Yiddish dialect performers as precursors. He mentions Willie Howard, who sang Yiddish words to Mexicanthemed skits (Caesar's Hours, 16). Fanny Brice comes to mind.

Caesar's approach to all his performance art is that it "had to have a basis in reality. It had to be believable". It is this believability - what Zukofsky called "sincerity" - that undercuts parody and irony: it allows language to be reinhabited ("objectification" in Zukofsky's sense) rather than mocked. This, in turn, connects to Zukofsky's "An Foin Lass" - a translation that brings home the Cavalcanti, makes it home and a little bit homely. The doubleness in doubletalk is, then, not deception or evasion but double consciousness in W. E. B. Du Bois's sense - the consciousness of the dominant English but the echo of the mamaloshen. It's not about a return to an authentic original language, it's the dialectial relation of the two, the echopoetics, that is the ground. Doubletalk that foregrounds doubletalking as its own kind of poetry or verbal acrobatics. And 
just to bring this point ever more homeward: Caesar would intersperse Yiddish and English words into his doubletalk routines. As he boasts, a Yiddish word pronounced the right way can sound Japanese.

Caesar's doubletalk uses the full prosodic resources of verbal language, foregrounding intonation, gesture, rhythm, syntax, and sound patterning rather than lexical identification. Doubletalk resembles sound poetry, but it is tied to the specific sounds and rhythms of the language being parodied. It is homophonic translation not of specific text but, rather, of the texture of the source language.

Like doubletalk, homophonic translation, zaum, sound poetry, and scat singing are not against expression; they are hyper-communicative. Sound writing makes meaning by other means (kio signifas per aliaj rimedoj in Esperanto); other, that is, than lexical. This is meaning for those who feel at home in the world, or want to make the world more homely (gemütlich, haimish). 'At home,' according to theologian Ernst Fuchs, 'one does not speak so that people will understand but because people understand. ${ }^{43}$ Language at home is marked by the temporal, transient, always in-process "presence of a dialect": "Here language is emotional. Its understanding of time ranges between song and shout" (p. 126).

The presence of the word, that is, verbing the word, is antinomian: the performance of language supersedes the law of language.

Only that which can become present as language is real. 'For where meaning is, there also is language. And where language is, there is reality. Language belongs so closely to reality that it sets reality free for the first time: language ex-presses reality. ...The word not merely conveys the concrete situation but creates it. ${ }^{34}$

In 1912, Franz Kafka gave an "Introductory Lecture on Jargon," a talk on Yiddish that he wrote as a prologue to a performance of Yiddish poetry. Yiddish represented for Kafka a "kind of immediacy of expression" in sharp contrast to the "endemic alienation of Western assimilated Jews" like himself. ${ }^{45}$ Yiddish, for Kafka, is related to Fuchs's idea of a language of home. At the same time, Kafka saw Yiddish as mißachtete, a disregarded and stigmatized dialect, a language appropriated from other language, and a subculture argot (a "minor language" as Gilles Deleuze and Felix Guattari have it in Kafka: Toward a Minor Literature). 
Caesar's homophonics are all about accent and accent is always a matter of class and ethnicity. In American culture, to have a marked accent is a stigma, a mark of your status as immigrant or ignorant. During Caesar's reign, people went to classes to lose their accent, or more accurate to say, learn the right accent. At the same time, in the years before the World War II, ethnic comedians had their audiences rolling in the aisles by performing their own and their audience's accents. This was the world of comedy Caesar came into. But it's one thing to make good fun with your own accent, another to mock the accents of others, which was also a staple of American ethnic comedy, which too often took an explicitly racist turn. Even if blackface performers identified with AfricanAmericans, it did not undercut the racism of the appropriation. Mimicry always risks being heard as ridicule or mockery.

Doubletalk is usually considered something bad, deceitful, fraudulent. Saying one thing and meaning another, a means of disguising the true meaning of something. It is connected with viral Jewish stereotypes, all repeatedly invoked in Pound's 1941-1943 Radio Rome speeches ${ }^{46}$ : the uprooted, usurpers of a language not rightly one's own, destroyers of the plain sense of the word and

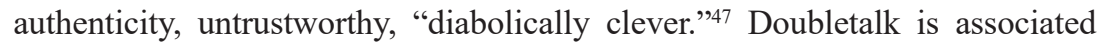
with gobbledygook, obfuscation, and gibberish - fake or counterfeit language, what George Orwell famously stigmatizes as doublespeak or bullshit, which gives "an appearance of solidity to pure wind." 48 It's the talk of carnival barkers, crooked politicians and kike lawyers, fascists and communists. It is nothing but bad faith. Doubletalk begins in the deliberately unintelligible and fragmented. Modernist poetry has often been tarred with this brush. It's fast talking on theory and chock full of elisions and evasions, obscure references, logical lapses, emotional bankruptcy; in other words, the kind of poetry I want. Caesar saw the poetry in these language textures, even if he would have figured them as "material" not "poetry." In the immediate wake of the extermination of the European Jews, he practiced a kind of shtick alchemy, turning the Jewish stigmas of accent and shyster into song, in the process turning the tools of intolerance and nationalism on their heads. Doubletalk is applied nomadics (to use Pierre Joris's term for non-national language ${ }^{49}$ ): it pushes back against blood and soil nativism. 
Excerpted and adapted from Sound / Writing: On Homophonic Translation, ed. Vincent Broqua and Dirk Weissmann (Paris: Éditions des archives contemporaines, 2020). First presented on November 17, 2016 at École Normale Supérieure, Paris, as the keynote for "Sound / Writing: On Homophonic Translation," an international trilingual colloquium, organized by Vincent Broqua and Dirk Weissmann. Translated by the author from Esperanto, "Duoble-Parolas la Homofonia Sublima: Komedio, Alproprigo, kaj la Sonoj de Unu Mano Kunfrapante.” An audio-visual supplement (ppt), including easy links to some of the works discussed, can be downloaded at writing.upenn.edu/ ezurl/10/.

Osip Mandelstam, "The Slate Ode (1923)," (Translated by Ian Probstein) in The River of Time: Time-Space, History, and Language in Avant-Garde, Modernist, and Contemporary Russian and Anglo-American Poetry, edited by Ian Probstein (New York: Academic Studies Press, 2017), 108. Cigale (Evanston, IL: Northwestern University Press, 2017), 104. 
Vincent Broqua and Bernstein, email exchange, Oct. 14, 2015.

"One thing to me instantly attractive is the sturdy resource of your ear, as Williams would say ...," Creeley wrote to me on Feb. 6, 1979, responding to Shade. The letter is included in Selected Letters of Robert Creeley, ed. Rod Smith, Peter Baker, and Kaplan Harris (Berkeley: University of California Press, 2014), 350. But there is typographical error in the published version, close to the kind of dyslexic inversion I often make: "the sturdy resources of your era," which recalls Zukofsky's paean, at the beginning of " $A$ "- 22, to the errors of the ear: "An era / any time / of year" ( " $A$, ” also from University of California Press, 1978; reprinted by New Directions in 2011). Olson's ear line is from "I, Maximus of Gloucester, to You" (1953); see the typescript at charlesolson.org/ Files/Maxlappendices/AppendixD.html.

See K. David Jackson, "Transcriação / Transcreation: The Brazilian Concrete Poets and Translation," In The Translator as Mediator of Cultures, ed. Humphrey Tonkin and Maria Esposito Frank (Amsterdam: John Benjamins Publishing Company, 2010).

David Anderson, "Editor's Introduction," in Pound's Cavalcanti (Princeton: Princeton University Press, 1983), ix.

See Lecercle's essay in Sound / Writing: On Homophonic Translation, ed. Vincent Broqua and Dirk Weissmann (Paris: Éditions des archives contemporaines, 2020).

There is a recording of Lehto and I reading this at PennSound $<$ writing.upenn.edu/pennsound $/ \mathrm{x} /$ Lehto.php>. I collected the poem in Recalculating (Chicago: University of Chicago Press, 2014), 29. The third version is Lehto's "barbaric" English translation in Lake Onega and Other Poems (Helsinki; ntamo), 19 and 143. See also Levi Lehto, Frederik Hertzberg, Bernstein, "On The Origins, State, and Future Perspectives of Finno-Saxon" (2004), The Conversant (2012): <theconversant. org/?p=1759>.

I reflect on these echoes of Mallarmé, Stevens, and Poe in "The Pataquerical Imagination: Midrashic Antinomianism and the Promise of Bent Studies," in Pitch of Poetry (Chicago: University of Chicago Press, 2016).

Heriberto Yépez, "Ulises Carrión's Mexican Discontinuities," in Ulises Carrión: Dear Reader. Don't Read, ed. Guy Schraenen (Madrid: Museo Nacional Centro de Arte Reina Sofía, 2016), 51.

Cited in "Artifice of Absorption" in my A Poetics (Cambridge: Harvard University Press, 1992), 58.

Al Kelly and Prof. Irwin Cory, both older than Caesar, pioneered the style. Caesar's own doubletalking professor is related to Cory's shtick (doubletalking in the sense of intellectual gibberish not foreign language mimicry). In a different vain, Ruth Draper in "The Actress," from around 1916, leaps into Slavic doubletalk: ruthdraper.com/selected-monologues/.

My American version was published in Recalculating, 94. I did a bilingual reading with Probstein, archived at PennSound with related recordings: writing.upenn.edu/pennsound/x/Khlebnikov.php.

Zaum is translated as both "trans-sense" and "beyond sense." According to Probstein, Khlebnikov "rejected borrowings from foreign languages and invented Russian words even for new scientific and technological phenomena. ... Although Khlebnikov supported the October revolution, he was more concerned with the future unity of all humankind: 'Fly, human constellation, / Further on, further into space / And merge the Earth's tongues / Into a single human conversation.' ... Both Khlebnikov and Kruchonykh spoke of zaum and 'the self-sufficient' word, but each interpreted those terms differently." Probstein quotes Khlebnikov on his search for "the magic touchstone of all Slavic words, ... a self-sufficient language" that provides a path to the "universal language" of zaum. - River of Time, 11, 15, 17.

Listen to Schwitters, Ball, and the Russian futurians on PennSound < writing.upenn.edu/pennsound $>$.

"Xenoglossia ... refers to the intelligible use of a natural language one has not learned formally or does not know and is distinguishable from ... glossolalia, or lexically incommunicative utterances. ... Such tales of miraculous translation evince a yearning for the promise of correspondence between languages, and thereby of erased cultural difference." Jennifer Scappetone, "Phrasebook 
Pentecosts and Daggering Lingua Francas in the Poetry of LaTasha N. Nevada Diggs," in The Fate of Difficulty in the Poetry of Our Time, edited by Charles Altieri and Nicholas D. Nace (Evanston, IL: Northwestern University Press, 2018), 265.

In What Makes Sound Patterns Expressive? The Poetic Mode of Speech Perception (Durham: Duke University Press, 1992), Reuven Tsur offers a groundwork for recognizing the expressivity of sound patterns, following Roman Jakobson's work on sound symbolism (sound iconicity). (Jakobson published a zaum collaboration with Alexei Kruchenykh in 1914 and wrote an essential account of Khlebnikov.) Tsur's cognitive poetics is immediately useful for literary sound studies. Born in 1932 in Transylvania, Tsur's native language is Hungarian. He started as a translator (into Hungarian and later Hebrew), getting his PhD at Sussex (UK). Now retired from Tel Aviv University, he still active in his research. He lives in Jerusalem. More Tsur at www.tau.ac.il/ tsurxx.

Gertrude Stein, "If I Told Him: A Completed Portrait of Picasso": writing.upenn.edu/pennsound/x/ Stein/If-I-Told-Him.php.

"The History of the Typewriter Recited by Michael Winslow": openculture.com/2014/06/thehistory-of-the-typewriter.html.

Robert Grenier, Sentences Toward Birds (Kensington, CA: L Publications, 1975), online at eclipse archive.org/projects/BIRDS/birds.html.

Hanna Tuulikki, "Air falbh leis na h-eòin - Away with the Birds" and "Guth an eEòin" - "Voice of the Bird": hannatuulikki.org/portfolio/awbirds and score.awaywiththebirds.co.uk.

John Bevins, aaaaw to zzzzd: The Word of Birds (Cambridge, MA: M.I.T Press, 2010), 48, 114. Bevins makes the argument for birdsong as music, comparing the experience to hearing songs in a foreign language (15-17) .

A poem I based on the sound of the song sparrow.

See Andrew Dodds, I, Sparkie (UK: Information as Material, 2013).

"Michael McClure Reads to Lions": jacket2.org/commentary/michael-mcclure-reads-lions.

German text quoted, along with a discussion of Anscombe's translation of Philosophical Investigations, in Marjorie Perloff, Wittgenstein's Ladder: Poetic Language and the Strangeness of the Ordinary (Chicago: University of Chicago Press, 1996), 74-75. See Ludwig Wittgenstein, Philosophical Investigations, tr. G.E.M. Anscombe, 2nd edition (Oxford: Blackwell, 1958), p. 223. The revised 4th edition of the translation by P. M. S. Hacker and Joachim Schulte (Blackwell, 2009) gives the line as "If a lion could talk, we wouldn't be able to understand it"; for Anscombe the lion is "him."

Sid Caesar, “The Poker Game,” Your Show of Shows (date unknown): youtu.be/RyNSFLkXTvA.

See Robin Seguy's 2015 hypertext presentations of the translations at text-works.org.

I. Kissen's Yiddish, “The Raven: Multingual,” cut 21:

Pound's Cavalcanti, p. 216. Pounds' commentary on "Donna mi prega" appeared in The Dial (with the subtitle "Medievalism") in 1928; this article included his translation in its first publication; a few years later it was collected in Make It New. See my related discussion in "Objectivist Blues," Attack of the Difficult Poems (Chicago: University of Chicago Press, 2011) 135-36. Nathan Kageyama reverses the dynamic in his translation of Pound's "The Return" into Hawaiian pidgin in Tinfish 3 (1996): writing.upenn.edu/epc/ezines/tinfish: "See, they return; ah, see the tentative / Movements, and the slow feet, / The trouble in the pace and the uncertain / Wavering!" becomes "Spock em, dey stay come; auwe, spock da scayed / Movaments, an' da luau feet, / Stay all twis' an' kooked / Walkin' all jag!" 
In 1940, Zukofsky privately circulated "A foin lass" in FIRST HALF of " $A$ "-9, a numbered and autographed edition of 55. Zukofsky included sources for "A"-9, including "Donna mi priegha [sic]," 22 pages on value and commodification excerpted from Marx's Capital and Value Price and Profit, a short excerpt from Stanley Allen's Electronics and Waves: A Short Introduction to Atomic Physics (1932), "translations of Cavalcanti's Canzone" by Pound (both versions) and vernacular versions by Jerry Reisman and Zukofsky, followed by a note on the form and "A"-9, first half, and concluding with a two-page "Restatement" of the poem. The first publication of "A foin lass" was in Zukofsky's Selected Poems, which I edited (New York: Library of America American Poets Project, 2006), 152. You can hear my performance of the poem at writing.upenn.edu/ezurl/5/ and Zukofsky's performance at writing.upenn.edu/ezurl/6/: Zukofsky performs it with a high, formal tone, neutralizing accent, while I emphasize a Yiddish/Brooklyn twang, performing a kind of "Jewface." I discuss "Jewface" in "Objectivist Blues" in Attack of the Difficult Poems, p. 142. (I heard Zukofsky's performance only after I had made my recording.)

Steve McCaffery, "Kommunist Manifesto": writing.upenn.edu/library/McCaffey-Steve

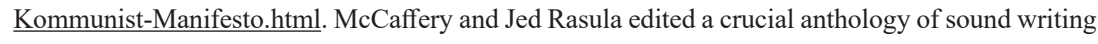
and invented vocabularies called Imagining Language (Cambridge, MA: M.I.T. Press, 1998). "Sound writing" echoes "sound poetry" and what Richard Kostelanetz anthologized as Text-Sound Texts (New York: William Morrow, 1980).

Performance by Joseph Guglielmi in the Paris studio of Anne Slacik on Oct. 11, 2015: writing. upenn.edu/pennsound/x/deformance.php.

"Sid Caesar Performing in Four Different Languages": writing.upenn.edu/ezurl/7, date unknown. See also: "Sid Caesar Double-Talk Routine" (interview) youtu.be/iL7efWcaVnk; "Sid Caesar, Le Grande Amour" youtu.be/JGHih5ISPhQ, French doubletalk film satire; "Sid Caesar, The Russian Arthur Godfrey" youtu.be/FHbscdj7OtU, Russian doubletalk, ending with Carl Reiner doing movie star impression in Russian doubletalk; and "Sid Caesar: Der Flying Ace" youtu.be/GhXRZ7yw7Nw. Caesar discusses "double-talk" in Sid Caesar with Eddy Friedfeld, Caesar's Hours: My Life in Comedy, with Love and Laughter (New York: Public Affairs, 2003), 58. "Sid Caesar's 80th Birthday Party" features a tour-de-force reprise, with Caesar, reading notes, doubletalking in French, German, Spanish, Italian, and Japanese youtu.be/FETaKPtdaJM.

Charles Reznikoff, "Joshua at Shechem," in Jerusalem the Golden in Complete Poems, vol. 1 (Santa Barbara, CA: Black Sparrow Press, 1976), 126.

Esther Schor, Bridges of Words: Esperanto and the Dream of a Universal Language (New York: Henry Holt, 2016), 63.

Avot Yeshurun, "Got fun Avrohom," Kapella Kolot (Tel Aviv: Siman Keriyah, 1977). Quoted by Neta Stahl in a review of Naomi Brenner's Lingering Bilingualism: Modern Hebrew and Yiddish Literatures in Contact in Comparative Literature 69:3 (2017), 350. The title of the poem means "God of Abraham" and refers to a Yiddish prayer for woman (mothers), to protect Israel from harm; Dizengoff Square is in Tel Aviv. For homophonic plays between Hebrew and Yiddish see Roy Greenwald, "Homophony in Multiligual Jewish Cultures," Dibur 1 (2016): arcade.stanford.edu/ dibur/homophony-multilingual-jewish-cultures (Greenwald discusses Yeshurun). I am grateful to Ariel Resnikoff for discussions about Yeshurun. See his essay, "Louis Zukofsky and Mikhl Likht, 'A Test of Jewish American Modernist Poetics"' in Jacket2 (2013): jacket2.org/commentary/arielresnikoff-louis-zukofsky-and-mikhl-likht-test-jewish-american-modernist-poetics-p-0.

See Marc Shell's discussion of these cartoons, as well as The Great Dictator (and, at least in citation, Modern Times) in terms of the macaronic, in Talking the Walk \& Walking the Talk: A Rhetoric of Rhythm (New York: Fordham University Press, 2015).

Ernst Fuchs, "The New Testament and the Hermeneutical Problem," in New Frontiers in Theology, vol. 2, The New Hermeneutic, tr. and ed. by James M. Robinson and John B. Cobb (New York: Harper and Row, 1964), 124 (italics removed). This quote, unsourced, comprises the 11th section of my “Three or Four Things I Know about Him," Content's Dream: Essays 1975-1985 (Los Angeles: Sun and Moon Press, 1985), 30. Fuchs's first name is incorrectly cited as "Eduard." 
Gerald G. O'Collins, “Reality as Language: Ernst Fuchs's Theology of Revelation,” Theological Studies 28/1 (Feb. 1967): 77-78. In internal quote, O’Collins translates Fuchs.

Richard T. Gray, Ruth V. Gross, Rolf J. Goebel, and Clayton Koelb, A Franz Kafka Encyclopedia (Westport, CT: Greenwood Press, 2005), 235. Eugene Ostachevsky pointed me to Kafka's talk.

See my 1984 "Pounding Fascism (Appropriating Ideology, Mystification, Aestheticization, and Authority in Pound's Poetic Practice)," collected in A Poetics (Cambridge: Harvard University Press, 1992).

Joseph Litvak, “Adorno Now," Victorian Studies 44/1 (2001): 37. Litvak discusses the relation of Theodor Adorno's use of dialect to Jewish comedians, including Caesar, especially when they turn highfalutin language into gibberish, as, Litvak notes, Adorno does to Heideggerian lingo: "How many of these jokes, that is, show the reversal as, precisely, an effect of gesture, where gesture is the part of language that, like a provincial accent or an unassimilated parent, embarrasses language? That the embarrassment should strike at the very moment when language is most concerned to make a good impression accounts, of course, for the particular sting with which the jokes themselves strike. Just when language thinks it has everything, especially itself, under control, it starts gesturing, or even gesticulating, thereby hysterically displaying one of the classic signs of an always excessive Jewish identity."

Orwell never uses the term "doublespeak" (or bullshit), though, in 1984, he writes about "doublethink" and "new speak"; those two terms, combined, suggest doublespeak. In his 1946 essay against the decay and corruption of language, "Politics and the English Language," Orwell argues for clear language and against obfuscating writing styles, what he calls "swindles and perversions." In some circumstance, his views offer practical advice; in others, they become a method of policing language and enforcing normalization: <orwell.ru/library/essays/politics/english/e_polit/>. 
Anderson, David. “Editor's Introduction.” In Pound's Cavalcanti. Princeton: Princeton University Press, 1983.

Bernstein, Charles. A Poetics. Cambridge: Harvard University Press, 1992.

Bernstein, Charles. "Thelonious Monk and the Performance of Poetry." In My Way: Speeches and Poems. Chicago: University of Chicago Press, 1999.

Bernstein, Charles. "The Pataquerical Imagination: Midrashic Antinomianism and the Promise of Bent Studies.” In Pitch of Poetry. Chicago: University of Chicago Press, 2016.

Bevins, John. aaaaw to zzzzd: The Word of Birds. Cambridge, MA: M.I.T Press, 2010.

Broqua, Vincent and Dirk Weissmann, eds. Sound / Writing: On Homophonic Translation. Paris: Éditions des archives contemporaines, 2020.

Dodds, Andrew. I, Sparkie. UK: Information as Material, 2013.

Gray, Richard T. , Ruth V. Gross, Rolf J. Goebel,and Clayton Koelb. A Franz Kafka Encyclopedia. Westport, CT: Greenwood Press, 2005.

Grenier, Robert. Sentences Toward Birds. Kensington, CA: L Publications , 1975. Available at: eclipsearchive.org/projects/BIRDS/birds.html.

Joris, Pierre. A Nomad Poetics. Wesleyan: Wesleyan University Press, 2003.

Jackson, K. David. "Transcriação / Transcreation: The Brazilian Concrete Poets and Translation." In The Translator as Mediator of Cultures, eds. Humphrey Tonkin and Maria Esposito Frank. Amsterdam: John Benjamins Publishing Company, 2010.

Kharms, Daniil. "From the Notebooks, Mid-1930s." In Russian Absurd: Selected Writings, tr. Alex Cigale. Evanston, IL: Northwestern University Press, 2017.

Litvak, Joseph. “Adorno Now.” Victorian Studies 44/1 (2001): 37.

Mandelstam, Osip. “The Slate Ode (1923)." (Translated by Ian Probstein) in The River of Time: Time-Space, History, and Language in Avant-Garde, Modernist, and Contemporary Russian and Anglo-American Poetry, edited by Ian Probstein. New York: Academic Studies Press, 2017.

O’Collins, Gerald G. "Reality as Language: Ernst Fuchs's Theology of Revelation.” Theological Studies 28/1 (Feb. 1967): 77-78.

Perloff, Marjorie. Wittgenstein's Ladder: Poetic Language and the Strangeness of the Ordinary. Chicago: University of Chicago Press, 1996.

Reznikoff, Charles. "Joshua at Shechem.” In Jerusalem the Golden in Complete Poems, vol. 1. Santa Barbara, CA: Black Sparrow Press, 1976.

Scappetone, Jennifer. "Phrasebook Pentecosts and Daggering Lingua Francas in the Poetry of LaTasha N. Nevada Diggs." In The Fate of Difficulty in the Poetry of Our Time, edited by Charles Altieri and Nicholas D. Nace. Evanston, IL: Northwestern University Press, 2018.

Schor, Esther. Bridges of Words: Esperanto and the Dream of a Universal Language. New York: Henry Holt, 2016.

Smith, Rod, Peter Baker, and Kaplan Harris, eds. Selected Letters of Robert Creeley. Berkeley: University of California Press, 2014.

Tsur, Reuven. What Makes Sound Patterns Expressive? The Poetic Mode of Speech Perception. Durham: Duke University Press, 1992.

Yépez, Heriberto. “Ulises Carrión’s Mexican Discontinuities." In Ulises Carrión: Dear Reader: Don't Read, ed. Guy Schraenen. Madrid: Museo Nacional Centro de Arte Reina Sofía, 2016. 
HEGELOVA ESTETIKA I SVETSKI MARKSIZAM: KOMUNISTIČKI IDEAL MIKHAILA LIFŠITSA

\section{Angela Harutyunyan}

Ovaj rad se bavi materijalističkim čitanjem Hegelove Estetike od strane sovjetskog filozofa Mihaila Lifšitsa (Mikhail Lifshits) iz njegovih spisa iz 1930-ih. Radeći na razvoju sovjetske marksističke teorije estetike, Lifšhits je prilagodio hegelovski koncept umetnosti kao vrste istine i aktualizacije Ideje u razumnom obliku kao idealnom. Medjutim, on je odbacio Hegelov tragični fatalizam u vezi sa istorijskom sudbinom umetnosti i njihovu podredjenost u novoj supra-čulnoj fazi razvoja Duha. Lifšits je tražio jedini odgovor na istorijsku sudbinu umetnosti u marksističkoj dijalektici istorije. Tu je identifikovao estetski ideal sa realizacijom komunizma. Na toj osnovi, tokom 1930-ih sovjetska teorija estetike kombinovala je čitanja Hegela, Marksa, Engelsa i Lenjina kako bi razvila sopstvenu verziju autonomije umetnosti, onu koja je utemeljena u konceptu ideala. Ideal je u svojoj istorijskoj i transistorijskoj dimenziji vidjen kao premošćivanje čulnosti i istine i usmeren prema komunističkom idealu. U radu se tvrdi da je ovaj koncept ideala ukazivao na dijalektičku budućnost koja nije mogla da podlegne zvaničnim staljinističkim formulacijama dijalektičkog materijalizma. Za razliku od staljinističke pobede „socijalizma u jednoj zemlji“ kao konzumacije istorijske dijalektike, pitanje istorijske sudbine umetnosti ukazalo je na komunizam kao nepotpun, a istorijski ostvariv ideal.

KLJUČNE REČI: HEGEL, MARKS, ESTETIKA, DIJALEKTIČKI MATERIJALIZAM, IDEAL, ČULNOST, ISTORIJSKA SUDBINA UMETNOST

\section{ODLOŽENA REAKCIJA NA HOMOFONSKU UZVIŠENOST: KOMEDIJA, PRISVAJANJE I ZVUKOVI JEDNE RUKE KOJA APLAUDIRA}

\section{Charles Bernstein}

Homofonski prevodi stvaraju pesme koje više ističu zvuk originala nego leksičko značenje. Započinjem raspravom o konceptu „Zvučnog pisanja“, pozivajući se na koncept „transkacije“ Harolda de Kamposa, Paundovu „transdukciju“ i koncept koji stoji iza kalka. Zatim razmatram svoje homofonske prevode finskog pesnika Levi Lehta (Leevi Lehto) i izofonski prevod Ulisesa Kariona (Ulises Carrión). Nakon ukazivanja na ideju Bazila Buntinga (Basil Bunting) da se značenje prenosi više zvukom neko leksičkim sadržajem, razmatram Hlebnikov (Khelbnikov) pristup zaumu (trans-značenje) i dela koja slično zvuče na osnovu pesme ptica ili zvukova životinja. U eseju se onda navodi nekoliko konkretnih primera: homofonski prevod Homera od strane Dejvida Melnika, prevod Magnetskih polja od strane Pjera Jorisa na osnovu prepoznavanja glasa i Džin Donelina verzija Ponža. Esej se završava diskusijom o knjizi Drift autorke Kerolin Bergval, njenoj verziji „The Seafarer", kao i njenim trans-kreacijama Čosera. U centralnom delu eseja se govori o „homofonskom“ prevodu u popularnoj kulturi, posebno „odloženoj reakciji“ Sida Cezara, najpopularnijeg TV komičara ranih 1950-ih. Diskusija o njegovom radu u kontekstu američke jevrejske komedije centralna je tema izlaganja. Ali drugi noviji popularni primer homofonije se obrađuje s posebnim osvrtom na kulturno prisvajanje.

KLJUČNE REČI: POEZIJA 20. VEKA, POETIKA, PREVOD, HOMOFONIJA, SID CEZAR, LUIS ZUKOFSKI, EZRA PAUND, KEROLIN BERGVAL, DEJVID MELNIK, JIDIŠ, ESPERANTO, PRISVAJANJE 